\section{A Novel Screening Method for Evaluation of Lettuce Germplasm for Bacterial Leaf Spot Resistance}

\author{
Huangjun $\mathrm{Lu}^{1}$ and Richard Raid \\ Everglades Research and Education Center, University of Florida/Institute \\ of Food and Agricultural Sciences, Belle Glade, FL 33430
}

Additional index words. Xanthomonas campestris pv. vitians, host-plant resistance, screening method, germplasm, cultivar, lettuce

\begin{abstract}
Bacterial leaf spot of lettuce, caused by Xanthomonas campestris pv. vitians, is a devastating disease of lettuce worldwide. Because there are no chemicals available for effective control of the disease, host-plant resistance is highly desirable to protect lettuce production. A new method for fast screening and accurate identification of bacterial leaf spot (BLS)-resistant lettuce has been developed in our laboratory. A total of 79 lettuce genotypes (69 germplasm lines and 10 adapted cultivars) were evaluated with this technique for response to $X$. $c$. vitians. Disease incidences ranged from $92 \%$ to $100 \%$ and disease severities were between 1.6 and 3.6 on the 0 to 4 scale. No highly resistant genotypes were identified. However, 12 genotypes did not significantly differ for disease severities from the moderately resistant 'Little Gem' lettuce that was used as a resistant control. Comparison of disease severities of 10 commercial cultivars and three moderately resistant germplasm lines tested at the seedling stage and adult stage showed a high positive correlation $(r=0.87, P<0.0001)$ between tests. The new screening method should be useful in breeding programs, in which great numbers of plants need to be tested during germplasm evaluation, and for single plant selection as well as other studies. The identification of new sources of moderate resistance in this study could facilitate development of cultivars with a higher level of resistance through the gene pyramiding approach.
\end{abstract}

Bacterial leaf spot of lettuce (Lactuca sativa L.), caused by Xanthomonas campestris pv. vitians, is an economically important disease of lettuce in the world (Barak et al., 2001; Patterson et al., 1986; Pennisi and Pane, 1990; Sahin, 2000; Sahin and Miller, 1997; Toussaint, 1999). A widespread and damaging outbreak of BLS in lettuce was first observed in Florida in the winter of 1992-93 (Pernezny et al.,1995). This disease has become problematic in Florida's lettuce production in recent years. In 2010, a severe epidemic caused significant crop damage and economic losses.

Typical BLS symptoms are brown to black, greasy-appearing lesions, which render the entire lettuce head unmarketable as a result of the unsightly leaf blemishes. There are no chemicals available for effective control of the disease. Therefore, use of host-plant resistance is the most efficient and desirable method to manage BLS in lettuce. Different types of lettuce have been found to vary in response to BLS with romaine and butterhead being highly susceptible (Carisse et al., 2000; Pernezny et al., 1995; Toussaint, 1999). Among crisphead, green, and red leaf lettuce, relatively resistant cultivars were identified in field (Carisse et al., 2000) and greenhouse experiments (Sahin and Miller, 1997). However,

Received for publication 10 Dec. 2012. Accepted for publication $8 \mathrm{Jan} .2013$.

${ }^{1}$ To whom reprint requests should be addressed; e-mail hjlu@ufl.edu. traits. This makes it difficult to transfer BLS resistance to adapted cultivars without affecting other traits of the adapted cultivars such as yield. The second concern is that 'Little Gem' exhibited BLS in the experiments of Bull et al. (2007) and our preliminary studies. The resistance in 'Little Gem' may not provide sufficient protection of lettuce if a BLS epidemic is extensive and severe in the field, as occurred in Florida in 1992-93 and in 2010. Therefore, efforts need to be made to screen additional cultivars and germplasm lines for new sources of resistance.

Two types of experiments (field and greenhouse) have been used to evaluate lettuce for response to BLS. In the field, plants were maintained according to standard commercial practices, sprayed with bacterial inoculum at thinning and again 2 weeks later, and rated for disease incidence and severity before harvest (Bull et al., 2007). In the greenhouse, lettuce was planted in either pots (Pernezny et al., 1995; Robinson et al., 2006) or cell flats (Bull et al., 2007), and up to three applications of inoculum to plants were made at a 7-d interval (Bull et al., 2007). These screening methods are labor-intensive and thus allow only a small number of cultivars to be tested at a time. For example, Carisse et al. (2000) evaluated only nine cultivars and Bull et al. (2007) tested 16 cultivars.

Breeding lettuce for BLS resistance usually requires testing a great number of plants during the initial screening of germplasm for resistant sources and during the plant selection stage to integrate the resistance into adapted cultivars. It is necessary to establish a method for fast and accurate evaluation of a large number of plants in a short period of time. We report development of a new screening method and identification of new sources of BLS resistance.

\section{Materials and Methods}

with resistance to BLS. However, there are two concerns with the use of 'Little Gem' for resistant cultivar development. The first is that 'Little Gem' is a small Latin lettuce and has undesirable agronomic and horticultural
Plant materials. A total of 79 lettuce cultivars were evaluated for response to BLS. Of these, 69 are germplasm lines, seeds

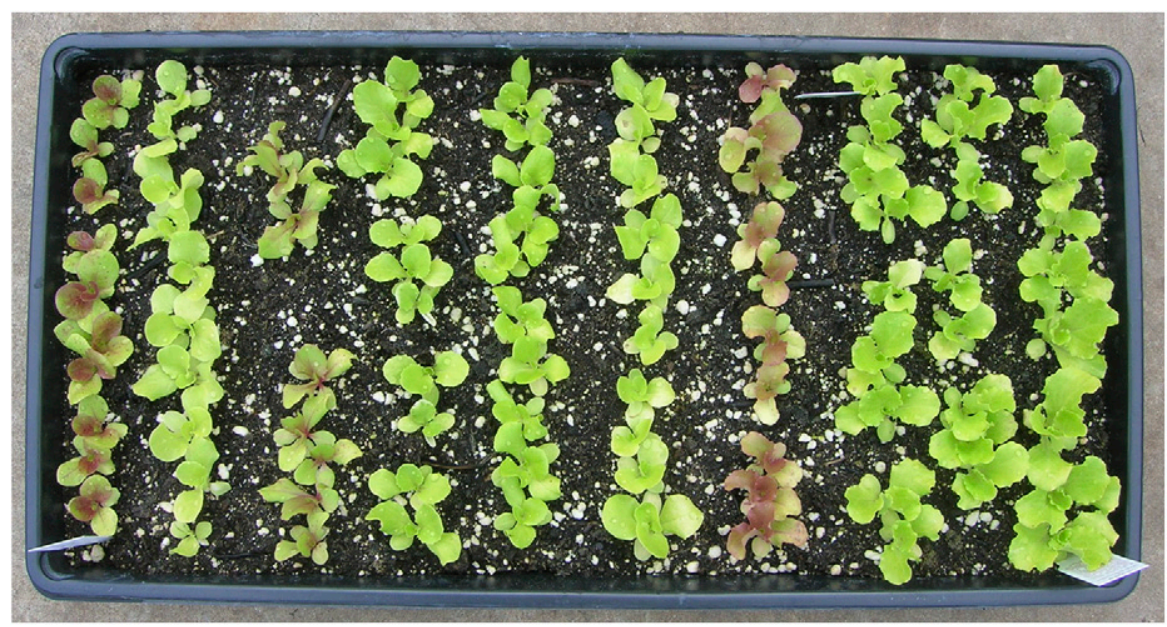

Fig. 1. Planting pattern of lettuce genotypes in a $30 \times 50$-cm flat. Ten genotypes with 10 seeds per genotype in a row were planted. 
Table 1. Disease incidences and severities of lettuce genotypes infected by X.c. vitians strain L7 3 weeks after inoculation.

\begin{tabular}{|c|c|c|c|c|}
\hline Line number & Germplasm name & Lettuce type & Disease incidence $^{z}$ & $\begin{array}{c}\text { Disease severity } \\
(0 \text { to } 4 \text { scale })^{\mathrm{y}}\end{array}$ \\
\hline 1 & 49889 & Crisphead & 100 & 3.6 \\
\hline 2 & Psr 1991-1 & Crisphead & 100 & 3.6 \\
\hline 3 & Tannex & Butterhead & 100 & 3.6 \\
\hline 4 & 47083 & Crisphead & 100 & 3.6 \\
\hline 5 & Floribibb & Butterhead & 100 & 3.5 \\
\hline 6 & 60154 & Crisphead & 100 & 3.5 \\
\hline 7 & 49674 & Crisphead & 100 & 3.4 \\
\hline 8 & 50098 & Romaine & 100 & 3.4 \\
\hline 9 & Lantana & Romaine & 100 & 3.4 \\
\hline 10 & 60159 & Crisphead & 100 & 3.4 \\
\hline 11 & 49530 & Butterhead & 100 & 3.4 \\
\hline 12 & 70202 & Butterhead & 100 & 3.4 \\
\hline 13 & Fla43007 & Romaine & 100 & 3.3 \\
\hline 14 & Terrapin & Romaine & 100 & 3.3 \\
\hline 15 & Okeechobee & Romaine & 100 & 3.3 \\
\hline 16 & 60167 & Crisphead & 100 & 3.3 \\
\hline 17 & 60183 & Romaine & 100 & 3.3 \\
\hline 18 & 50103 & Crisphead & 100 & 3.3 \\
\hline 19 & 9285 & Crisphead & 100 & 3.3 \\
\hline 20 & 8074 & Crisphead & 100 & 3.3 \\
\hline 21 & Morgana & Butterhead & 100 & 3.2 \\
\hline 22 & 60174 & Butterhead & 100 & 3.2 \\
\hline 23 & Shawnee & Crisphead & 100 & 3.2 \\
\hline 24 & Manatee & Romaine & 100 & 3.2 \\
\hline 25 & Armelle & Butterhead & 100 & 3.1 \\
\hline 26 & 60173 & Butterhead & 100 & 3.1 \\
\hline 27 & 1265 & Crisphead & 100 & 3.1 \\
\hline 28 & 60155 & Crisphead & 100 & 3.1 \\
\hline 29 & Floricrisp & Crisphead & 100 & 3.1 \\
\hline 30 & 60160 & Crisphead & 100 & 3.1 \\
\hline 31 & 60148 & Crisphead & 100 & 3.1 \\
\hline 32 & 60166 & Crisphead & 97 & 3.1 \\
\hline 33 & 60150 & Crisphead & 100 & 3.0 \\
\hline 34 & 60178 & Butterhead & 100 & 3.0 \\
\hline 35 & 49758 & Crisphead & 100 & 3.0 \\
\hline 36 & 1508 & Crisphead & 100 & 3.0 \\
\hline 37 & 18076 & Butterhead & 100 & 3.0 \\
\hline 38 & 70096 & Romaine & 100 & 3.0 \\
\hline 39 & 1993-3 & Crisphead & 100 & 2.9 \\
\hline 40 & 70096 & Romaine & 100 & 2.9 \\
\hline 41 & 47079 & Crisphead & 100 & 2.9 \\
\hline 42 & h1089 & Crisphead & 100 & 2.9 \\
\hline 43 & 45060 & Butterhead & 95 & 2.9 \\
\hline 44 & 60184 & Romaine & 100 & 2.9 \\
\hline 45 & 60171 & Crisphead & 100 & 2.9 \\
\hline 46 & 60156 & Crisphead & 100 & 2.9 \\
\hline 47 & h2020 & Crisphead & 100 & 2.8 \\
\hline 48 & h1075 & Crisphead & 100 & 2.8 \\
\hline 49 & 60168 & Crisphead & 100 & 2.8 \\
\hline 50 & 60157 & Crisphead & 100 & 2.8 \\
\hline 51 & 60180 & Crisphead & 100 & 2.8 \\
\hline 52 & Glades & Romaine & 100 & 2.7 \\
\hline 53 & 49017 & Romaine & 100 & 2.7 \\
\hline 54 & 60179 & Butterhead & 100 & 2.7 \\
\hline 55 & 46087 & Crisphead & 100 & 2.7 \\
\hline 56 & 1443 & Crisphead & 95 & 2.7 \\
\hline 57 & 49019 & Crisphead & 100 & 2.6 \\
\hline 58 & Isolde & Crisphead & 100 & 2.6 \\
\hline 59 & h1059 & Crisphead & 100 & 2.6 \\
\hline 60 & 60158 & Crisphead & 100 & 2.6 \\
\hline 61 & 1502 & Crisphead & 97 & 2.6 \\
\hline 62 & 60176 & Butterhead & 100 & 2.5 \\
\hline 63 & Hamlet & Crisphead & 100 & 2.5 \\
\hline 64 & 49404 & Crisphead & 100 & 2.5 \\
\hline 65 & 60169 & Crisphead & 100 & 2.5 \\
\hline 66 & 48060 & Butterhead & 100 & 2.5 \\
\hline 67 & 49085 & Crisphead & 92 & 2.5 \\
\hline 68 & h1078 & Crisphead & 100 & 2.4 \\
\hline 69 & h1098 & Crisphead & 100 & 2.4 \\
\hline 70 & 60163 & Crisphead & 100 & 2.3 \\
\hline 71 & Gator & Crisphead & 100 & 2.3 \\
\hline 72 & Raleigh & Crisphead & 100 & 2.3 \\
\hline
\end{tabular}

(Continued on next page) of which were stored in the cold $\left(2\right.$ to $\left.5^{\circ} \mathrm{C}\right)$ storage room at University of Florida/IFAS Everglades Research and Education Center, Belle Glade, FL, and the remaining 10 are adapted cultivars used in Florida's lettuce production. The 69 germplasm lines consist of 48 crisphead, seven romaine, and 14 butterhead types. The 10 adapted cultivars are composed of five crisphead ('Raleigh', 'Gator', 'Glades', '8074', and '9285') and five romaine ('Terrapin', 'Okeechobee', 'Manatee', 'Lantana', and '70096') cultivars. 'Little Gem' was used as a resistant control. The germplasm lines were first grown in a greenhouse to generate fresh seed for testing. Ten seeds of each genotype were germinated in a single row with 10 rows for 10 cultivars in a $30 \times 50-\mathrm{cm}$ flat filled with Fafard 2 Mix containing Canadian sphagnum peat $(70 \%)$, perlite, and vermiculite (Conrad Fafard Inc., Agawam, MA) (Fig. 1). The genotypes were randomly arranged in the flats. Nitrogen fertilizer was applied by broadcasting $8 \mathrm{~g}$ urea and phosphorus fertilizer was applied by broadcasting $10 \mathrm{~g}$ superphosphate to each flat. The flats were watered and then placed on an outside bench to receive full sunlight under a mist irrigation system that automatically turned on for $5 \mathrm{~min}$ each day.

Disease screening. $X$. campestris pv. vitians strain L7, recovered from a commercial lettuce field in 1993 by Pernezny et al. (1995), was used in the present study. Stock cultures were stored in $15 \%$ aqueous glycerol at $-70{ }^{\circ} \mathrm{C}$. Preparation of inoculum was similar to that described in Robinson et al. (2006). Bacteria were streaked on glucose nutrient agar plates (GNA) and placed in an incubator for $3 \mathrm{~d}$ at $28{ }^{\circ} \mathrm{C}$. Plates were then flooded with sterile, phosphate-buffered saline. Bacteria were loosened with a glass rod and poured into a beaker. The suspensions were diluted to $\approx 1 \times 10^{8}$ colonyforming units $/ \mathrm{mL}$ with more buffer and were stirred on a stir plate with a magnetic bar for $\approx 10 \mathrm{~min}$. One drop of Tween 80 was added to $100 \mathrm{~mL}$ of inoculum suspension to enhance wetting of leaf surfaces.

At the six- to eight-leaf stage, the flats were moved into the greenhouse for bacterial inoculation. Plants were inoculated by inoculum by misting plant leaves to runoff using a handheld sprayer. After inoculation, the flats were placed into plastic bags to keep sufficient moisture for $24 \mathrm{~h}$. The plants were then removed from the bags and kept in the greenhouse. Overhead sprinkler irrigation was used to water the plants until runoff once a day. Temperatures in the greenhouse were maintained between 20 and $28{ }^{\circ} \mathrm{C}$. After 3 weeks, plants were scored for determination of disease incidence and severity. Disease incidence was calculated by dividing the number of diseased plants by the total number of plants of each germplasm line and expressed as percentage of plants exhibiting infection. Disease severity was evaluated using the rating system as described in Bull et al. (2007) with modifications: $0=$ no symptoms on a plant; $1=$ one to 10 lesions 
Table 1. (Continued) Disease incidences and severities of lettuce genotypes infected by X.c. vitians strain L7 3 weeks after inoculation.

\begin{tabular}{lclcc}
\hline Line number & Germplasm name & Lettuce type & Disease incidence $^{\mathrm{z}}$ & $\begin{array}{c}\text { Disease severity } \\
(0 \text { to } 4 \text { scale })^{\mathrm{y}}\end{array}$ \\
\hline 73 & b1192 & Crisphead & 100 & 2.2 \\
74 & 60182 & Romaine & 100 & 2.2 \\
75 & 60172 & Crisphead & 100 & 2.2 \\
76 & 50101 & Romaine & 100 & 2.1 \\
77 & h2033 & Crisphead & 100 & 2.1 \\
78 & 60161 & Crisphead & 92 & 1.8 \\
79 & Minetto & Crisphead & 100 & 1.7 \\
80 & Little Gem & Latin & 100 & 1.6 \\
LSD $(0.05)^{\mathrm{x}}$ & & & & 0.839 \\
\hline
\end{tabular}

${ }^{2}$ Disease incidence was expressed as percentage of plants exhibiting infection.

${ }^{y}$ Disease severity was evaluated using the rating system as described in Bull et al. (2007) with modifications: $0=$ (no symptoms on a plant); $1=$ (one to 10 lesions of less than $3 \mathrm{~mm}$ ); $2=$ (more than 10 lesions of less than $3 \mathrm{~mm}$ ); 3 = (lesions of greater than $3 \mathrm{~mm}$ ); and $4=$ (coalesced lesions).

${ }^{x} \mathrm{LSD}=$ least significant difference.

Table 2. Comparisons of disease severities of 10 current commercial lettuce cultivars in Florida and three moderately resistant germplasm lines infected by X.c. vitians strain L7 in seedling test and adult plant test.

\begin{tabular}{llll}
\hline & & \multicolumn{2}{c}{$\begin{array}{c}\text { Disease severity } \\
(0 \text { to } 4 \text { scale })^{\mathrm{z}}\end{array}$} \\
\cline { 3 - 4 } & & $\begin{array}{c}\text { Seedling } \\
\text { test }^{\mathrm{y}}\end{array}$ & $\begin{array}{c}\text { Adult } \\
\text { test }^{\mathrm{y}}\end{array}$ \\
Genotype & Type & $3.5 \mathrm{a}$ & $3.6 \mathrm{a}$ \\
Terrapin & Romaine & $3.8 \mathrm{a}$ & $2.8 \mathrm{~cd}$ \\
Lantana & Romaine & $3.4 \mathrm{a}$ & $3.1 \mathrm{abcd}$ \\
Okeechobee & Romaine & $3.3 \mathrm{ab}$ & $3.4 \mathrm{ab}$ \\
9285 & Crisphead & $3.3 \mathrm{ab}$ & $3.4 \mathrm{ab}$ \\
Manatee & Romaine & $3.2 \mathrm{ab}$ & $2.9 \mathrm{bcd}$ \\
8074 & Crisphead & $3.1 \mathrm{abc}$ & $3.3 \mathrm{abc}$ \\
70096 & Romaine & $3.0 \mathrm{bc}$ & $2.7 \mathrm{~d}$ \\
Gator & Crisphead & $2.8 \mathrm{c}$ & $3.2 \mathrm{abcd}$ \\
Glades & Crisphead & $2.3 \mathrm{~d}$ & $2.8 \mathrm{~cd}$ \\
Raleigh & Crisphead & $2.2 \mathrm{de}$ & $2.7 \mathrm{~d}$ \\
60161 & Crisphead & $1.9 \mathrm{ef}$ & $1.6 \mathrm{e}$ \\
Minetto & Crisphead & $1.8 \mathrm{ef}$ & $1.8 \mathrm{e}$ \\
Little Gem & Latin & $1.7 \mathrm{f}$ & $1.4 \mathrm{e}$ \\
\hline
\end{tabular}

${ }^{2}$ Disease severity was evaluated using the rating system as described in Bull et al. (2007) with modifications: $0=$ (no symptoms on a plant $) ; 1=$ (one to 10 lesions of less than $3 \mathrm{~mm}$ ); 2 = (more than 10 lesions of less than $3 \mathrm{~mm}$ ); $3=$ (lesions of greater than $3 \mathrm{~mm}$ ); and $4=$ (coalesced lesions).

y Means in the column followed by the same letter are not significantly different $(a=0.05)$ using a least significant difference test (Version 9.2; SAS Institute, Cary, NC).

of less than $3 \mathrm{~mm} ; 2=$ more than 10 lesions of less than $3 \mathrm{~mm} ; 3$ = lesions of greater than $3 \mathrm{~mm}$; and $4=$ coalesced lesions. Genotypes with an average score of 0 to 0.9 were classified as highly resistant, 1.0 to 1.9 as moderately resistant, 2.0 to 2.9 moderately susceptible, and greater than 3.0 as susceptible. The experiment was repeated three times.

To understand the relationship between disease responses of seedlings and adults of genotypes of interest, the 10 modern cultivars, the two best resistant lines identified in the previously described experiment, and 'Little Gem' were further tested for seedling response in flats and adult plant response in pots. The seedling test was conducted in the manner as described above. For the adult test, fifteen 10 -inch pots were planted to a single genotype. The soil was the same as described above but $10 \mathrm{~g}$ fertilizer (Scout 14-14-14) was initially added and two months later, an additional $6 \mathrm{~g}$ was applied to each pot to provide nitrogen, phosphorus, and potassium. Pots were placed on an outside bench for seed to germinate under a mist irrigation system. One week later, the pots were moved into the greenhouse and arranged in three replications of a randomized complete block. Irrigation was applied by a mist system. At approximately the 15 -leaf stage $(\approx 8$ weeks after planting), plants were inoculated using the method described above and then were kept in plastic bags for $24 \mathrm{~h}$. The pots were removed from the bags and kept in the greenhouse with the temperature between 20 and $28{ }^{\circ} \mathrm{C}$. One week later, the plants were inoculated again with the bacteria. Plants were rated for disease 3 weeks after the second inoculation using the same scale system as described previously.

Data analysis. Data were analyzed with the GLM procedure of SAS (Version 9.2; SAS Institute, Cary, NC). The least significant difference test (Steel and Torrie, 1980) was used for comparison of the differences of means among the cultivars at the 5\% level of significance. Correlation analysis was conducted to understand the relationships between seedling disease severity and adult disease severity using SAS Proc Corr (Version 9.2; SAS Institute).

\section{Results and Discussion}

In the seedling test, plants began to exhibit symptoms $\approx 2$ weeks post-inoculation. The disease progressed in a manner similar to that observed on lettuce in field, from watersoaked lesions to black lesions, then to coalesced lesions, which eventually became dry and papery on susceptible cultivars. The disease incidences were high, ranging from $92 \%$ to $100 \%$ among the cultivars including the resistant control 'Little Gem' (Table 1). The disease severities ranged from 1.6 to 3.6. These results demonstrate that the new screening method was effective in promoting bacterial infection and disease development. There are several advantages associated with this screening method. First, because a $30 \times$ $50-\mathrm{cm}$ flat can hold 100 plants, a large number of plants can be evaluated within a small space at a single time. Second, the high plant density holds the moisture for a longer period. This favors disease development and progression. Third, we used only one application of the inoculum. This not only saves time and costs, but also eliminates the potential confounding effects caused by multiple inoculations. Fourth, there is a high degree of uniformity as indicated by the high disease incidence among the genotypes; thus, the screening method should be useful in breeding programs for germplasm evaluation and single plant selection as well as in other studies.

Lettuce genotypes differed significantly in responses to BLS (Table 1). Among 79 genotypes tested, 38 had an average disease severity of greater than 3.0 and 39 had a disease severity between 2.0 and 2.9. Therefore, $97 \%$ of the genotypes were rated susceptible or moderately susceptible. No highly resistant genotypes were detected in this study because there were no genotypes having a disease severity below 1.0. However, two lines were classified as moderately resistant because of their relatively low disease severity ( 1.7 for ' 60161 ' and 1.8 for 'Minetto'). The control, 'Little Gem', had a disease incidence of $100 \%$ and disease severity of 1.6 , which was not significantly different from those of '60161' and 'Minetto'. Our results are in agreement with those of Bull et al. (2007) and Carisse et al. (2000) who observed significant variations for response to BLS among the lettuce cultivars.

In both seedling and adult tests, significant variations were still observed among the 10 cultivars, two germplasm lines, and the resistant control 'Little Gem' (Table 2). The two lines ('60161' and 'Minetto') and 'Little Gem' still expressed stronger BLS resistance than any cultivars except for 'Raleigh', which did not significantly differ from the two lines in the seedling test. Responses to $X$. $c$. vitians were similar in seedling stage and adult stage as indicated by the positive correlation coefficient $(r=0.87, P<0.0001)$. Therefore, evaluation for response to $X$. c. vitians at the seedling stage can be generally used to infer adult response.

In the present study, we did not see any lettuce genotypes that had stronger BLS resistance than the resistant control, 'Little Gem', although 79 genotypes were screened. Additional germplasm should be screened to identify sources of stronger resistance. However, the genotypes with disease severities that were not significantly different from that of 'Little Gem' will also be useful. If further research identifies different chromosomal loci for BLS resistance from these genotypes, new cultivars with higher levels of resistance can be developed by the breeding approach of pyramiding resistance genes into a single genotype (Huang et al., 1997; Tar'an et al., 2003).

The X. c. vitians strain L7 used in the present study was isolated from a commercial lettuce field in Florida during an extensive BLS outbreak in 1993 (Pernezny et al., 1995). This strain has been used as a bacterial source to study virulence to different types of lettuce (Pernezny et al., 1995), BLS epidemiology 
(Robinson et al., 2006), and BLS management of lettuce (Pernezny et al., 2002). No more than three lettuce genotypes were tested in each of those studies. In the present study, we tested 79 lettuce genotypes including 53 crisphead, 12 romaine, and 14 butterhead using L7 as inoculum. L7 caused disease on all of the genotypes indicating that L7 is highly virulent to lettuce. However, the disease severities varied significantly among the lettuce genotypes, which led to identification of the moderately resistant genotypes, including 'Little Gem'. It appears that L7 has an ability similar to that of the mixture of strains Xav 98-12, BS 339, and BS 347 (Bull et al., 2007) to distinguish the resistant lettuce from susceptible ones. Therefore, L7 should prove useful in serving as one source of inoculum not only for plant pathological studies as epidemiology and disease management, but also for plant breeding, to help identify resistant sources for development of cultivars.

\section{Conclusions}

In this article, we described a new method for fast screening of a large number of lettuce germplasm for resistance to BLS caused by X. c. vitians. A total of 79 lettuce genotypes representing crisphead, romaine, and butterhead lettuce were evaluated with this method for response to $X$. c. vitians. Disease incidences were high, ranging from $92 \%$ to $100 \%$. Disease severities were between 1.6 and 3.6 on the 0 to 4 scale. No highly resistant genotypes were identified in the 79 genotypes. However, there were 12 genotypes that did not significantly differ for disease severities from the resistant control, 'Little Gem'. Correlation analysis on disease severities of 10 commercial cultivars and three moderately resistant germplasm lines tested at the seedling stage and adult stage indicated a high positive correlation $(r=0.87, P<0.0001)$ between tests.

\section{Literature Cited}

Barak, J.D., S.T. Koike, and R.L. Gilbertson. 2001. The role of crop debris and weeds in the epidemiology of bacterial leaf spot of lettuce in California. Plant Dis. 85:169-178.

Bull, C.T., P.H. Goldman, R. Hayes, L.V. Madden, S.T. Koike, and E. Ryder. 2007. Genetic diversity of lettuce for resistance to bacterial leaf spot caused by Xanthomonas campestris pv. vitians. Plant Health Prog. doi: 10.1094/PHP2007-0917-02-RS.

Carisse, O., A. Ouimet, and V. Toussaint. 2000. Evaluation of the effect of seed treatments, bactericides, and cultivars on bacterial leaf spot of lettuce caused by Xanthomonas campestris pv. vitians. Plant Dis. 84:295-299.

Huang, N., E.R. Angeles, J. Domingo, G. Magpantay, S. Singh, G. Zhang, N. Kumaravadivel, J. Bennett, and G.S. Khush. 1997. Pyramiding of bacterial blight resistance genes in rice: Marker-assisted selection using RFLP and PCR. Theor. Appl. Genet. 95:313-320.

Patterson, C.L., R.G. Grogan, and R.N. Campbell. 1986. Economically important diseases of lettuce. Plant Dis. 70:982-987.
Pennisi, A.M. and A. Pane. 1990. Graviepidemie di Xanthomonas campestris pv. vitians (brown) Dye su lattuga in Sicilia. Inf. Fitopatol. 40: $56-58$.

Pernezny, K., R. Nagata, R.N. Raid, R.J. Collins, and A. Carroll. 2002. Investigation of seed treatments for management of bacterial leaf spot of lettuce. Plant Dis. 86:151-155.

Pernezny, K., R.N. Raid, R.E. Stall, N.C. Hodge, and J. Collins. 1995. An outbreak of bacterial spot of lettuce in Florida caused by Xanthomonas campestris pv. vitians. Plant Dis. 79:359-360.

Robinson, P.E., J.B. Jones, and K. Pernezny. 2006. Bacterial leaf spot of lettuce: Relationship of temperature to infection and potential host range of Xanthomonas campestris pv. vitians. Plant Dis. 90:465-470.

Sahin, F. 2000. First report of bacterial spot of lettuce caused by Xanthomonas campestris pv. vitians in Turkey. Plant Dis. 84:490.

Sahin, F. and S.A. Miller. 1997. Identification of the bacterial leaf spot of lettuce, Xanthomonas campestris pv. vitians in Ohio, and assessment of cultivar resistance and seed treatments. Plant Dis. 81:1443-1446.

Steel, R.G.D. and J.H. Torrie. 1980. Principles and procedures of statistics. 2nd Ed. McGraw-Hill, New York, NY.

Tar'an, B., L. Buchwaldt, A. Tullu, S. Banniza, T.D. Warkentin, and A. Vandenberg. 2003. Using molecular markers to pyramid genes for resistance to ascochyta blight and anthracnose in lentil (Lens culinaris Medik). Euphytica 134:223-230.

Toussaint, V. 1999. Bacterial leaf spot, a new disease of lettuce in Quebec caused by Xanthomonas campestris pv. vitians. Phytoprotection 80:121125 . 